\title{
Research on Risk Management of Green Supply Chain of Prefabricated Buildings Based on QCA
}

\author{
Hongxiong Yang ${ }^{1}$, Wanru Ren ${ }^{2, *}$ \\ ${ }^{1}$ School of Management, Tianjin University of Technology, Tianjin, China. \\ ${ }^{2}$ School of Management, Tianjin University of Technology, Tianjin, China.
}

\begin{abstract}
In the context of sustainable development, green supply chain, as a whole-process environmental management model, provides a good implementation path for the development and utilization of prefabricated buildings. However, the green supply chain operation of prefabricated buildings in a complex social network environment involves many risk factors, which seriously affect the realization of the green supply chain management goals. This research first identifies risk factors based on the perspective of stakeholders, and then uses fsQCA to analyze the risk factors in the green supply chain of prefabricated buildings, and identifies four configurations that lead to high risks in the green supply chain of prefabricated buildings. Risk is the main risk that leads to the risk of the green supply chain of prefabricated buildings. The types of core risks involved mainly include externality risks, organizational management risks, and manufacturing risks. This research provides an effective method for evaluating and reducing risks in the green supply chain of prefabricated buildings, and improves the effectiveness and accuracy of risk control by all participants.
\end{abstract}

\section{Introduction}

Compared with traditional buildings, prefabricated buildings have changed the previous mode of production in the construction industry, focusing on integrated production, and there are many participating companies with a high degree of vertical integration. It not only emphasizes the integration of technology, information, capital and management, but also pursues "greening" at each stage of the entire life cycle. In this context, the implementation of green supply chain management for prefabricated buildings has become an effective way to enhance the core strength and economic performance of the enterprise, save resources, protect the environment, and alleviate the contradictions among the economy, environment and society. Green supply chain looks at each participant in the supply chain from a holistic perspective, fully considers the internal and external connections between each participant, emphasizes resource efficiency and the compatibility of behavioral activities with the environment, and focuses on the whole process environmental management ${ }^{[1]}$. However, there are a large number of participants in the green supply chain of prefabricated buildings, and there are many links involved. They not only face problems in technology, standards, system integration, organization, cost, management and ecological environment, but also come from outside the green supply chain operation Obstacle factors such as gender, information asymmetry and members' selfinterest. Therefore, the implementation of green supply chain management in prefabricated buildings faces huge risks.

The existence of many risk factors will make the entire life cycle of prefabricated buildings have a complicated influence relationship, and seriously disrupt the operation of the green supply chain. However, there are very few researches on the risks of the green supply chain of prefabricated buildings. Existing risk studies mostly focus on safety ${ }^{[2]}$,quality ${ }^{[3]}$, project development, production and manufacturing, or study prefabricated building supply chain risks from the perspective of corporate economic benefits. Existing studies all regard risk factors as isolated points, focusing on the analysis of risk factors and the independence of stakeholders, and lack of research on the entire green supply chain risk from the entire life cycle of prefabricated buildings. Therefore, this research is based on the configuration perspective, through fsQCA, the prefabricated building green supply chain risk factors are incorporated into the common research framework to identify core risks and configuration relationships. The research results are helpful to improve the risk management knowledge system of prefabricated building green supply chain, and help practitioners to deal with these risks more effectively.

\section{Overview of Green Supply Chain Risks in Prefabricated}

\subsection{Stakeholder Research}

Supply chain risk management refers to the identification and management of supply chain risks through

\footnotetext{
* Corresponding author:874144468@qq.com
} 
coordination among supply chain members to reduce the vulnerability of the entire supply chain, emphasizing the risk identification and management process. Luo (2019) studied the schedule risk in the prefabricated building supply chain from the perspective of stakeholders ${ }^{[4]}$. The role of stakeholders involves not only the stakeholders within the enterprise, but also suppliers, consumers, and even government departments, local community residents and social organizations. Prefabricated construction projects are in a complex social network environment. There are many participants in the green supply chain. Among them, the chain mainly includes owners, design units, suppliers, manufacturing subcontractors, transporters, construction subcontractors, and returnees. It is composed of units, supervision units, property units and final consumers, and outside the chain includes government and related policy organizations, environmental protection organizations and community residents. The interest appeals of stakeholders in the green supply chain mainly revolve around economic benefits, social benefits and environmental benefits. Various stakeholders have different positions and pursuits in the entire green supply chain, and their emphasis on the three benefits is naturally different. Based on the conflict analysis of stakeholders, this study classified the stakeholders of the green supply chain of prefabricated buildings into 6 categories: government, core enterprises in the supply chain and upstream and downstream enterprises, employees, communities, environmental protection organizations and customers.

\subsection{Risk factor identification}

Conflicts between stakeholders have become the most important source of risk in the current green supply chain of prefabricated buildings. Prefabricated building projects have a long construction period and involve many links. This makes green supply chain risks both from internal risks in the manufacturing stage. , There are also external and intermediate risks from the operating environment of the green supply chain. Through sorting out and investigating existing research on prefabricated construction projects, the risks of the green supply chain of prefabricated buildings are divided into three categories: external risks, internal risks and intermediate risks. The external risks include environmental risks, political and legal risks, and market risks; Internal risks include external risks, organizational management risks, manufacturing risks and recycling risks; intermediate risks include information risks and cooperation risks ${ }^{[5]}$.

\section{Research method}

\subsection{Data collection}

Existing research is more commonly used to explore single-factor linear relationship using binary relationship statistical methods. This research discards traditional research methods and attempts to use fuzzy set fsQCA method to explore prefabricated building green supply chain risk management issues based on ensemble theoretical models. The questionnaire survey method is used to collect data, and the questionnaires are distributed through e-mail, the Internet and on-site. The respondents to the questionnaire involve all participants in the green supply chain of prefabricated buildings. A total of 148 questionnaires were recovered. Through preliminary review of the questionnaires, 9 questionnaires were found to have obvious regularity. After all such questionnaires were eliminated, 139 valid questionnaires were finally obtained, with an effective recovery rate of $89.33 \%$.

\subsection{Variable measurement and calibration}

First, sort out the risk factor indicators of each risk type based on existing research, as shown in Table 1. Then construct a Likert five-level scale suitable for this research situation, and after obtaining the data, according to the substantive theoretical knowledge, the original scale values of all variables are converted into fuzzy membership scores by the calibration method. Based on the existing research, this paper draws on the calibration method of Fiss (2011) on Likert scale measurement variables, set "5" as the "full membership point", select "3" as the "cross point", and set "1" as the "Completely not affiliated point"[6], run the "compute" command on other variables to automatically perform calibration conversion.

Table 1. Measurement of Risk Factors in Green Supply Chain of Prefabricated Buildings

\begin{tabular}{|c|c|}
\hline Type of risk & Measurement standard \\
\hline \multicolumn{2}{|l|}{ External risk } \\
\hline $\begin{array}{l}\text { Environmental } \\
\text { risk }\end{array}$ & Force majeure, weather conditions \\
\hline $\begin{array}{l}\text { Political and } \\
\text { legal risks }\end{array}$ & $\begin{array}{l}\text { Policies, regulations, standards and } \\
\text { regulations; Slow government approvals } \\
\text { and unreasonable interference }\end{array}$ \\
\hline Market risk & $\begin{array}{l}\text { Fluctuations in market demand; } \\
\text { Insufficient consumer awareness of } \\
\text { prefabricated buildings; Changes in } \\
\text { inflation, interest rates and exchange rates }\end{array}$ \\
\hline \multicolumn{2}{|l|}{ Internal risk } \\
\hline External risk & $\begin{array}{l}\text { Manufacturing externalities; Consumption } \\
\text { concepts and methods; Technology and } \\
\text { knowledge }\end{array}$ \\
\hline $\begin{array}{l}\text { Organization } \\
\text { management } \\
\text { risk }\end{array}$ & $\begin{array}{l}\text { Unreasonable supply chain structure and } \\
\text { lack of flexibility; Lack of experience in } \\
\text { green operation and management; } \\
\text { Inconsistent strategic goals; Lack of green } \\
\text { commitments in the supply chain }\end{array}$ \\
\hline $\begin{array}{l}\text { Manufacturing } \\
\text { risk }\end{array}$ & $\begin{array}{l}\text { Procurement of product quality; Limited } \\
\text { suppliers to choose from; Green } \\
\text { products/materials with long lead times; } \\
\text { Design changes; Personnel capabilities } \\
\text { and mobility; Parts integration and low } \\
\text { degree of modularization; Engineering } \\
\text { quality and schedule control; Rationality } \\
\text { of transportation standards }\end{array}$ \\
\hline Recycling risk & $\begin{array}{l}\text { Business conflicts; Risk of reverse } \\
\text { logistics design; Difficulty in recycling; } \\
\text { Insufficient cost estimation }\end{array}$ \\
\hline \multicolumn{2}{|c|}{ Intermediate risk } \\
\hline $\begin{array}{l}\text { Information } \\
\text { risk }\end{array}$ & $\begin{array}{l}\text { Low level of information; Asymmetric } \\
\text { information }\end{array}$ \\
\hline
\end{tabular}




\begin{tabular}{|l|l|}
\hline $\begin{array}{l}\text { Cooperation } \\
\text { risk }\end{array}$ & $\begin{array}{l}\text { Inadequate understanding of green } \\
\text { requirements leads to breach of contract; } \\
\text { Poor relationships among supply chain } \\
\text { partners; uneven distribution of benefits }\end{array}$ \\
\hline
\end{tabular}

\section{Analysis results}

\subsection{Necessity analysis of antecedent variables}

Before the configuration analysis of the antecedent variables, the consistency and coverage of the antecedent variables must be calculated to assess whether the risk of the green supply chain of prefabricated buildings has the necessary conditions, that is, the necessity analysis of each antecedent variable, As shown in table 2. The consistency level of the antecedent variables in the necessity test does not exceed the threshold of 0.9 (the standard for determining the necessary level ${ }^{[7]}$. It can be considered that no single antecedent variable becomes a necessary condition for high innovation performance or non-high innovation performance.

Table 2. Necessity analysis

\begin{tabular}{|l|l|l|}
\hline \multirow{2}{*}{ Condition variable } & \multicolumn{2}{c|}{ Outcome variable } \\
\cline { 2 - 3 } Environmental risk & 0.518855 & 0.532869 \\
\hline$\sim$ Environmental Risk & 0.559852 & 0.558870 \\
\hline Political and legal risks & 0.808555 & 0.585767 \\
\hline$\sim$ Politics and Law & 0.588697 & 0.620501 \\
\hline Market risk & 0.592685 & 0.523836 \\
\hline$\sim$ Market risk & 0.615968 & 0.502028 \\
\hline External risk & 0.682515 & 0.589606 \\
\hline$\sim$ External risk & 0.639187 & 0.561236 \\
\hline Organization management risk & 0.570935 & 0.525620 \\
\hline$\sim$ Organization management risk & 0.725227 & 0.508730 \\
\hline Manufacturing risk & 0.697623 & 0.555516 \\
\hline$\sim$ Manufacturing Risk & 0.726513 & 0.735259 \\
\hline Recycling risk & 0.562955 & 0.556922 \\
\hline$\sim$ Recycling risk & 0.588166 & 0.769755 \\
\hline Information risk & 0.695351 & 0.588611 \\
\hline$\sim$ Information Risk & 0.695351 & 0.588611 \\
\hline Cooperation risk & 0.566903 & 0.731159 \\
\hline$\sim$ Cooperation risk & 0.675231 & 0.599521 \\
\hline
\end{tabular}

Note: “ ” refers to logical negation

\subsection{Configuration analysis}

Using fsQCA3.0 software to analyze the configuration of green supply chain risk in prefabricated buildings, based on fuzzy set directional comparison and analysis of corresponding operation rules, the frequency threshold and consistency threshold are set to 1 and 0.8 respectively for causality adequacy assessment, and the corresponding There are four configurations $(\mathrm{H} 1 \mathrm{a}, \mathrm{H} 1 \mathrm{~b}, \mathrm{H} 2, \mathrm{H} 3)$ that lead to high risks in the green supply chain of prefabricated buildings, as shown in Table 3. The consistency level of the individual solution and the overall solution of each configuration is higher than the minimum acceptable consistency level of 0.75 ; the overall solution coverage of the green supply chain risk of the prefabricated building is 0.68 , which explains the equivalent in the sample cases Part of the coverage. In order to ensure the robustness of the results, this paper conducted a robustness test on the high-risk antecedent condition configuration, and raised the case frequency threshold from 1 to 2 . The results found that it is basically the same as the configuration that causes high risk in the green supply chain of prefabricated buildings Therefore, the results of this study can be determined to be robust.

Table 3 Prefabricated building green supply chain risk management configuration

\begin{tabular}{|c|c|c|c|c|}
\hline \multirow[t]{2}{*}{ Type of risk } & \multicolumn{4}{|c|}{$\begin{array}{l}\text { Fabricated building green supply } \\
\text { chain risky configuration solution }\end{array}$} \\
\hline & $\mathrm{H} 1 \mathrm{a}$ & $\mathrm{H} 1 \mathrm{~b}$ & $\mathrm{H} 2$ & H3 \\
\hline \multicolumn{5}{|l|}{ External risk } \\
\hline Environmental risk & $\otimes$ & $\otimes$ & $\otimes$ & \\
\hline $\begin{array}{l}\text { Political and legal } \\
\text { risks }\end{array}$ & & & & - \\
\hline Market risk & & 0 & & • \\
\hline \multicolumn{5}{|l|}{ Internal risk } \\
\hline External risk & 0 & $\bullet$ & $\bullet$ & \\
\hline \multicolumn{5}{|l|}{$\begin{array}{l}\text { Organization } \\
\text { management risk }\end{array}$} \\
\hline Manufacturing risk & $\bullet$ & - & - & 0 \\
\hline Recycling risk & $\bullet$ & & $\bullet$ & \\
\hline \multicolumn{5}{|l|}{ Intermediate risk } \\
\hline Information risk & & $\bullet$ & & $\bullet$ \\
\hline Cooperation risk & $\otimes$ & $\otimes$ & & \\
\hline consistency & 0.8423 & 0.7981 & 0.8723 & 0.7843 \\
\hline raw coverage & 0.4325 & 0.2857 & 0.3994 & 0.2724 \\
\hline unique coverage & 0.1423 & 0.0629 & 0.1958 & 0.0723 \\
\hline $\begin{array}{l}\text { Solution } \\
\text { consistency }\end{array}$ & \multicolumn{4}{|c|}{0.795834} \\
\hline Solution coverage & \multicolumn{4}{|c|}{0.683436} \\
\hline
\end{tabular}

Note: indicates that the core causal condition exists, $\otimes$ indicates that the core causal condition is absent, $\mathbf{0}$ indicates that the marginal causal condition exists, $\otimes$ indicates that the marginal causal condition is absent, and the blank indicates that the condition may or may not appear in the configuration.

(1) External risk dominance (H1a, H1b). Configuration H1a indicates that when manufacturing risks and recycling risks exist as edge conditions, and environmental risks and cooperation risks are missing as edge conditions, externality risks are the core conditions leading to high risks in the green supply chain of prefabricated buildings; configuration $\mathrm{H} 1 \mathrm{~b}$ indicates that when production Manufacturing risks and information risks exist as marginal conditions, and when environmental risks and cooperation risks are missing as marginal conditions, externality risks and market risks are the core conditions leading to high risks in the green supply chain of prefabricated buildings. 
(2) Risk-oriented organization and management (H2). Configuration $\mathrm{H} 2$ shows that when environmental risk is missing as a core condition, organizational management risk is the core condition leading to high risks in the green supply chain of prefabricated buildings, and other internal risks exist as marginal conditions.

(3) Manufacturing risk-oriented type (H3). Configuration $\mathrm{H} 3$ shows that manufacturing risks are the core conditions leading to high risks in the green supply chain of prefabricated buildings. At the same time, political and legal risks, market risks and information risks exist as marginal conditions.

\section{Conclusion and discussion}

Based on the full life cycle of prefabricated buildings and the configuration perspective, this research incorporates prefabricated building green supply chain risk factors into a common research framework through fsQCA, and identifies four main configurations that lead to prefabricated green supply chain risks. The configuration results of green supply chain risk management for prefabricated buildings show that internal risks are the main risks that lead to green supply chain risks for prefabricated buildings. The types of core risks involved mainly include external risks, organizational management risks, and manufacturing risks. The core enterprises of the supply chain and upstream and downstream enterprises are the largest participants in the green supply chain of prefabricated buildings. They usually get the most profits, but they also need to bear huge risks. Therefore, the risk control of the core enterprises in the supply chain and upstream and downstream enterprises is the key to the risk control of the entire green supply chain of prefabricated buildings. Although the government, customers and communities are not involved in many risk factors, they can significantly affect the activities of various actors in the green supply chain system and cannot be ignored.

(1) Aiming at external risks, by giving full play to the government's coercive force, innovating the regulatory mechanism, promoting the whole-process supervision of prefabricated buildings, establishing a green credit (certification) rating system, establishing a government incentive mechanism; increasing social supervision; establishing internal and external enterprises Incentive mechanism involves the incentive mechanism of all internal employees and the restraint mechanism between enterprises.

(2) In response to organizational management risks, build a green corporate culture by improving the green and sustainable development concepts of corporate leaders; cultivate professional talents through policy support and the combination of production, education and research, and establish professional identification and talent training standards.

(3) In view of manufacturing risks, focus on technological integration and innovation, follow the principle of modulus coordination and standardization throughout the entire process; focus on management innovation, establish a management system that conforms to prefabricated buildings, and strengthen mechanism innovation in quality management and other aspects.

The research results are helpful to improve the risk management knowledge system of green supply chain of prefabricated buildings, provide effective evasion methods for assessing and reducing the risks of green supply chain of prefabricated buildings, and improve the effectiveness and accuracy of risk control by all participants, and help practitioners deal with these risks more specifically.

\section{References}

1. Mangla S K, Kumar P, Barua M K. Prioritizing the responses to manage risks in green supply chain: An Indian plastic manufacturer perspective[J]. Sustainable Production\&Consumption, 2015, 1:6786.

2. Li Haoran, Li Qiming, Lu Ying. Analysis of key safety risks in prefabricated building construction based on structural equation model.[J].China Safety Science Journal, 2019, 29(04):171-176.

3. Qu Fuqiang, Chen Chuyi, Yan Wei. Quality Risk Assessment of Prefabricated Building Components Based on ANP-FUZZY[J]. Journal of Civil Engineering and Management, 2019, 36(03):92-98.

4. Luo L, Shen G Q, Xu G, et al. Stakeholder Associated Supply Chain Risks and Their Interactions in a Prefabricated Building Project in Hong Kong[J]. Journal of Management in Engineering, 2019, 35(2):94-107.

5. Sang Peidong, Li Jinxiao. Risk Evaluation of Prefabricated Buildings Development and Construction Based on Structural Equation[J]. Journal of Civil Engineering and Management, 2017,34(04):89-95.

6. Fiss P C. Building Better Causal Theories: A Fuzzy Set Approach to Typologies in Organization Research $[\mathrm{J}]$. Academy of Management Journal, 2011,54(2):393-420.

7. Du Yunzhou, Jia Liangding. Configuration perspective and qualitative comparative analysis (QCA):a new way of management research[J]. Management World, 2017(06):155-167. 